Dariusz Brzegowy, Dominujące tytuły w sprawach o stwierdzenie nieważności małżeństwa w Sądzie Diecezjalnym w Tarnowie w latach 1945-1983, [w:] Struktura i działalność Sądu Diecezjalnego w Tarnowie w latach 1945-1983, red. Robert Kantor, Kraków 2019, s. 143-155.

DoI: http://dx.doi.org/10.15633/9788374387309.08

KS. DARIUSZ BRZEgowy

Sąd Diecezjalny w Tarnowie

\title{
Dominujące tytuły \\ w sprawach o stwierdzenie \\ nieważności małżeństwa \\ w Sądzie Diecezjalnym w Tarnowie \\ w latach 1945-1983
}

Przedmiotem kwerendy umożliwiającej prezentację tytułowego zagadnienia były sprawy o stwierdzenie nieważności małżeństwa przyjęte do rozpatrzenia przez Sąd Diecezjalny w Tarnowie w perspektywie czasowej, którą rozpoczyna zakończenie II wojny światowej w Europie - tj. od 8 maja 1945 roku. Punktem końcowym zaś interesującego nas okresu jest 26 listopada 1983 roku, czyli ostatni dzień vacatio legis obecnie obowiązującego Kodeksu prawa kanonicznego, promulgowanego przez Świętego Jana Pawła II Konstytucją apostolską Sacrae disciplinae leges z 25 stycznia 1983 roku'. Należy zatem zauważyć, że czasowa przestrzeń niniejszego studium podlega regulacji Kodeksu pio-benedyktyńskiego i wynosi prawie 40 lat, w których trakcie zarówno Kościół powszechny, jak i diecezja tarnowska ulegały rozmaitym przeobrażeniom.

1 Codex Iuris Canonici auctoritate Ioannis Pauli PP. II promulgatus, 25.01.1983, „Acta Apostolicae Sedis" [dalej: AAs] 75 (1983) pars II, s. VII-XIV; tekst łacińsko-polski: Kodeks prawa kanonicznego, przekład zatwierdzony przez Konferencję Episkopatu Polski, Poznań 1984 . 
Wypada zaznaczyć, że artykuł nie ma charakteru statystycznego², zajęto się tym już bowiem w innym studium ${ }^{3}$; nie jest też próbą syntezy czy naukowego komentarza dotyczącego wybranych obszarów jurysprudencji sądu tarnowskiego wypracowanej we wspomnianym wyżej okresie ze względu na jego ograniczone ramy. Zasadniczym celem tego opracowania jest syntetyczne ukazanie 3 dominujących tytułów nieważności małżeństwa (jakimi są: przymus i bojaźń, wykluczenie zgody małżeńskiej oraz niezdolność do jej wyrażenia z przyczyn natury psychicznej) wraz z ich legalnym zakotwiczeniem, którym były, jak będziemy mieli okazję się przekonać na wstępie każdego z trzech kolejnych paragrafów, nie tylko odpowiednie dyspozycje Kodeksu prawa kanonicznego z 1917 roku, lecz również autorytatywny dorobek orzecznictwa Roty Rzymskiej.

Pragniemy nadmienić, że poważnym utrudnieniem badawczym pozostają niewątpliwie brak katalogu zbiorów akt i dokumentów sądowych, przechowywanych w siedzibie Archiwum Diecezjalnego, a także niekompletność akt niektórych spraw. W konsekwencji dane przyjęte za punkt wyjścia do niniejszych rozważań bazują wyłącznie na księgach rejestracji poszczególnych spraw, przechowywanych w notariacie Sądu Diecezjalnego. Procesy, o jakich mówimy, posiadają numerację od 284 do 1608 i znajdują się w 5 kolejnych tomach ksiąg procesowych (od II do vi).

\section{Przymus i bojaźń}

Najczęściej przyjmowanym przez diecezjalny sąd tarnowski w powojennym okresie obowiązywania Kodeksu pio-benedyktyńskiego tytułem nieważności małżeństwa były przymus i bojaźń ( 527 spraw).

Nie ulega wątpliwości, że akt zgody nupturientów rozumiany jako przyczyna sprawcza małżeństwa winien być w pełni ludzki, tzn. odznaczać się

2 Nie stanowią zatem przedmiotu naszego zainteresowania chociażby kwalifikacja tytułów nieważności małżeństwa ze względu na określoną stronę procesową, a także stopień, w którym sprawa była rozstrzygana przez trybunał tarnowski, sposób zakończenia instancji (wyrok, umorzenie czy też zrzeczenie się) oraz jej materialne rozstrzygnięcie, mające miejsce również w kolejnej (i ewentualnie dalszej) instancji.

3 Por. G. Salamon, Ogólne zestawienie procesów w Sądzie Diecezjalnym w Tarnowie 1945-1983 w niniejszej publikacji. 
uprzednim poznaniem przedmiotu oraz świadomym i wolnym dookreśleniem woli. Domaga się tego bowiem nie tylko powaga związku małżeńskiego i wynikające zeń konsekwencje, ale przede wszystkim godność osoby ludzkiej, stworzonej przez Boga i na Jego obraz. W konsekwencji nikt nie może zostać zmuszony do zawarcia małżeństwa z określoną osobą, a świadome i poważne naruszenie wolności podmiotu w tej kwestii jest zarówno aktem moralnie niegodziwym, jak i działaniem odbierającym mu moc prawną.

Kodeks prawa kanonicznego z 1917 roku w kan. $1087 \$ 1$ określił wpływ przymusu na ważność zgody małżeńskiej, stanowiąc, że „nieważne jest małżeństwo zawarte pod przymusem lub pod wpływem ciężkiej i niesprawiedliwie wywołanej bojaźni z zewnątrz, od której, ażeby się uwolnić, zmuszony jest ktoś wybrać małżeństwo"4. Sukcesywny zaś paragraf niniejszego kanonu potwierdzał, iż „żadna inna bojaźń, chociażby była przyczyną zawarcia małżeństwa, nie pociąga za sobą jego nieważności”.

W świetle przytoczonej dyspozycji, analizowanej przez doktrynę i judykaturę rotalną, należy stwierdzić, że - w ujęciu Kodeksu prawa kanonicznego z 1917 roku - o nieważności małżeństwa powstałej wskutek przymusu i wynikającej zeń bojaźni można było mówić jedynie wtedy, gdy zostały spełnione równocześnie 4 warunki:

1. lęk winien być wywołany przez czynnik zewnętrzny (nie zaś wewnętrzny, mający swe źródło w zaburzonej psychice nupturienta), będący skutkiem działania człowieka ${ }^{6}$;

2. wywołany lęk winien być poważny, a w ocenie tego stanu należy uwzględnić zarówno zdolność urzeczywistnienia przez gnębiciela wysuwanych gróźb, jak i stopień grożącego ofierze zła, oceniany przede wszystkim relatywnie, nie zaś wyłącznie obiektywnie; trzeba zaznaczyć, że stan ducha ofiary winien być określany z uwzględnieniem jej płci,

4 Codex Iuris Canonici, Pii X P.M. iussu digestus, Benedicti P. xv auctoritate promulgatus, AAS 9 (1917) pars II, s. 1-593 [dalej: KPK 17], kan. $1087 \$ 1$ : „invalidum quoque est matrimonium initum ob vim vel metum gravem ab extrinseco et iniuste incussum, a quo ut quis se liberet, eligere cogatur matrimonium".

5 KPK 17, kan. $1087 \$ 2$ : „Nullus alius metus, etiamsi det causam contractui matrimonii nullitatem secumfert".

6 Por. wyrok c. Masala z 8.07.1969, „Tribunal Apostolicum Sacrae Rotae Romanae. Decisiones seu Sententiae" [dalej: SRRDec.] 61 (1969), s. 732. 
wieku, wykształcenia i posiadanych zdolności, a także okoliczności, w jakich się znajduje;

3. bojaźń winna być wywołana w sposób niesprawiedliwy, tj. przez kogoś, kto nie ma prawa narzucenia danej osobie konieczności zawarcia małżeństwa, a przymuszonemu, który w żaden sposób nie ma obowiązku zawierać takiego małżeństwa, winno grozić wyrządzenie krzywdy ${ }^{8}$;

4. jedynym sposobem uniknięcia grożącego ofierze zła jest zawarcie przez nią małżeństwa $\mathrm{z}$ określoną osobą ${ }^{9}$.

Należy dodać, że jednym z rodzajów lęku jest tzw. bojaźń szacunkowa (timor reverentialis), zachodząca pomiędzy osobami pozostającymi w relacji o charakterze zależności lub estymy, np. dziećmi i rodzicami czy też prawnymi opiekunami. Jakkolwiek ci ostatni przez roztropne rady powinni być dla osób poddanych swojej pieczy przewodnikami w procesie zakładania rodziny, nie wolno im jednak poprzez przymus bezpośredni lub pośredni wpływać na decyzje dzieci dotyczące małżeństwa lub wyboru współmałżonka. To pryncypium wyznaczone przez Sobór Watykański $\mathrm{II}^{10}$, bazujące na prawie naturalnym, znalazło również zastosowanie i rozwinięcie w orzecznictwie rotalnym, zgodnie z którym bojaźń szacunkowa, uznawana ze swej natury za lekką, może stać się poważna po uwzględnieniu zaistniałych okoliczności, takich jak wyrzuty lub groźby, usilne i uciążliwe naciski itp. W niektórych zaś wypadkach należy uznać ją za poważną nawet bez stwierdzenia obecności tych czynników, zwłaszcza gdy chodzi o relacje dzieci do rodziców ${ }^{11}$.

Próbując wyjaśnić fenomen prymatu wspomnianego tytułu nieważności $\mathrm{w}$ realiach społeczno-kościelnych diecezji tarnowskiej w analizowanym okresie, pierwszorzędnie należy wskazać na przeważający model rodziny, bardzo często wielodzietnej i z dominującą rolą ojca będącego źródłem

7 Por. wyrok c. Fiore z 14.05.1983, „Apostolicum Rotae Romanae Tribunal Sententiae seu Decisiones" 75 (1983), s. 285.

${ }^{8}$ Por. wyrok c. Masala z 8.07.1969, sRrdec. 61 (1969), s. 732. Jak zauważa Klaus Lüdicke, wśród przyczyn, które w świetle omawianej dyspozycji uzasadniałyby roszczenie przymuszającego do zawarcia małżeństwa, można wyróżnić uwiedzenie bądź zaręczyny. Por. K. Lüdicke, Przymus i bojaźń w kan. 1087 KPK z 1917 r. i w kan. 1103 KPK z 1983 r., „Ius Matrimoniale" 1 (1996) nr 6/7, s. 31-32.

9 Por. wyrok c. Masala z 31.05.1969, sRRDec. 61 (1969), s. 582.

${ }^{10}$ Por. Sobór Watykański II, konst. Gaudium et spes, n. 52.

${ }^{11}$ Por. wyrok c. Masala z 8.07.1969, sRRDec. 61 (1969), s. 732. 
utrzymania, rozumianego jako instancja wytyczająca bieg życia domowników, władna decydować o ich postawach i wyborach, w tym również o zawarciu małżeństwa. W takim kontekście rodzinnym dzieci (a zwłaszcza córki), pozostające całkowicie w ekonomicznej zależności od rodziców i niemające perspektyw rychłego usamodzielnienia się, a także wychowane w duchu bezwarunkowego czy wręcz ślepego posłuszeństwa i karności, bardzo często w procesie decyzyjnym dotyczącym małżeństwa musiały uwzględniać stanowisko rodziców, nierzadko motywowane wyłącznie czysto ambicjonalnymi bądź ekonomiczno-społecznymi względami. Warto tutaj wskazać przypadek, w którym kontekst decyzji o zawarciu małżeństwa został wytworzony poprzez nieoczekiwaną ciążę kobiety, w tej bowiem sytuacji pozostawanie bez ślubu pociągało za sobą środowiskową infamię, zarówno wobec rodziców poczętego dziecka, jak i ich rodzin. Było to podyktowane charakterem panujących ówcześnie stosunków społecznych, definiowanych przez pryzmat niewielkich lub wręcz hermetycznych grup i skupisk, bez możliwości zachowania anonimowości, zwłaszcza w sferze relacji małżeńskich i rodzinnych. Nie sposób nie dotknąć w tym miejscu również kwestii religijnej wrażliwości, odwołującej się do poczucia odpowiedzialności stron za poczęte życie i piętnującej wszelkie istniejące poza utrwalonym wzorcem małżeństwa i rodziny związki (np. konkubinat lub kontrakt regulowany prawem cywilnym). Mentalność ta, pomimo słusznie negatywnej oceny wspomnianych związków i bazowania w dużej mierze na niewzruszonym nauczaniu Magisterium Kościoła o świętości związku małżeńskiego i rodziny, była jednak niekiedy wypaczana przez błędne przekonanie o słuszności autorytatywnego narzucania drogi małżeńskiej osobie, którą z przyszłym współmałżonkiem nie łączyło nic poza nieoczekiwanym faktem poczęcia dziecka. Takie małżeństwo szybko doświadczało kryzysu, czego skutkiem były stopniowe oddalanie się stron i sukcesywny rozpad wspólnoty, małżonkowie zaś, związani przeszkodą węzła, nie mogli zawrzeć kolejnego związku z wybranym już dobrowolnie partnerem bez uprzedniego pozytywnego wyroku w swojej sprawie.

\section{Symulacja zgody małżeńskiej}

Drugim tytułem, gdy chodzi o częstotliwość występowania w sprawach o stwierdzenie nieważności małżeństwa prowadzonych przez trybunał 
tarnowski w analizowanym okresie jego działalności, była symulacja (wykluczenie) zgody małżeńskiej. Tytuł ten został przyjęty do rozpatrzenia w 387 przypadkach.

Pomimo tego, iż kan. $124 \$ 2$ obecnie obowiązującego KPK, stwierdzający, że akt prawny dokonany właściwie co do swych elementów zewnętrznych uważa się za ważny ${ }^{12}$, nie ma swojego poprzednika w kodyfikacji pio-benedyktyńskiej, to $\mathrm{w}$ obszarze unormowań prawa małżeńskiego można znaleźć w niej domniemanie ustawowe o takim charakterze. Wystarczy bowiem wskazać kan. 1014, który mówi, że „małżeństwo cieszy się przychylnością prawa, dlatego w wątpliwości należy uważać je za ważne, dopóki nie udowodni się czegoś przeciwnego, z zachowaniem przepisu

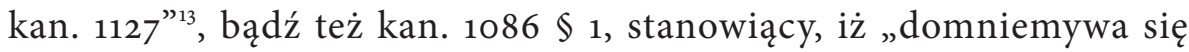
zawsze, że wewnętrzna zgoda odpowiada słowom lub znakom użytym przy zawieraniu małżeństwa"14.

Ustawodawca kodeksowy przewidział jednak sytuację, w której jeden z nupturientów (lub obydwoje) wykluczy samo małżeństwo bądź jeden $z$ jego istotnych przymiotów (np. jedność, nierozerwalność, otwartość na posiadanie potomstwa) ${ }^{15}$. Zachodzi wtedy brak łączności pomiędzy wewnętrzną wolą kontrahenta a jej zewnętrzną manifestacją, co w konsekwencji i zgodnie z brzmieniem kan. $1086 \$ 2$ powoduje nieważność małżeństwa ${ }^{16}$. Stosownie do intencji ustawodawcy kościelnego i dorobku orzecznictwa Roty Rzymskiej koniecznym warunkiem zaistnienia symulacji było wykluczenie dokonane przez pozytywny akt

${ }^{12}$ Dyspozycja ta, będąca domniemaniem ustawowym ważności aktu prawnego, posiada doniosłe znaczenie, jeśli chodzi o porządek prawny Kościoła, jest bowiem rękojmią stałości i pewności prawnej jako jednych z fundamentalnych cech, jakimi winny odznaczać się czynności tworzące lub modyfikujące relacje prawne zachodzące pomiędzy różnymi podmiotami w Kościele. Oznacza ona również przeniesienie ciężaru dowodzenia - na tego, kto twierdzi przeciwnie.

${ }^{13}$ KPK 17, kan. 1014: „Matrimonium gaudet favore iuris; quare in dubio standum est pro valore matrimonii, donec contrarium probetur, salvo praescripto can. 1127". Wspomniany wyjątek dotyczy przychylności prawa w wypadku wątpliwości co do przywileju wiary.

${ }_{14}^{14}$ KPK 17, kan. $1086 \$ 1$ : „Internus animi consensus semper praesumitur conformis verbis vel signis in celebrando matrimonio adhibitis".

${ }_{15}$ Por. wyrok c. Ferraro z 21.02.1969, SRRDec. 61 (1969), s. 164-165.

${ }^{16}$ KPK 17, kan. $1086 \$ 2$ : „At si alterutra vel utraque pars positive voluntatis actu excludat matrimonium ipsum, aut omne ius ad coniugalem actum, vel essentialem aliquam matrimonii proprietatem, invalide contrahit". 
woli, tzn. decyzję skierowaną ku niezawieraniu określonego małżeństwa bądź zawarciu go w sposób ograniczony ${ }^{17}$.

W odniesieniu do niniejszego tytułu warto zauważyć, że był on przyjmowany w trybunale tarnowskim niemalże wyłącznie jako całkowite wykluczenie zgody małżeńskiej, bez ewentualnych specyfikacji dotyczących konkretnego przymiotu, którego eliminacja pociągałaby za sobą nieważność małżeństwa. Pomimo uwzględnienia psychologicznej i prawnej złożoności fenomenu wykluczenia, nierzadko nastręczającej poważnych trudności na etapie rozpoznawania sprawy, trzeba jednak zaznaczyć, że taki sposób jego ujmowania w procesie mógł być wynikiem przesadnie asekuracyjnej postawy sędziego, a także, czego nie można wyłączyć, skutkiem dość pobieżnego potraktowania danych zawartych w skardze powodowej.

\section{Niezdolność do wyrażenia zgody małżeńskiej z przyczyn natury psychicznej}

Jak można łatwo zauważyć, wskazany w tytule niniejszego paragrafu trzeci z kolei najczęściej przyjmowany tytuł nieważności małżeństwa jest sformułowaniem bardzo szerokim i zarazem umownym. W wyniku przeprowadzonych badań zaobserwowaliśmy bowiem następujące sformułowania tytułów dotyczących tej sfery: niezdolność wynikająca z przyczyn natury psychicznej - 177 przypadków, amencja (obłęd, pomieszanie zmysłów, choroba psychiczna) - 80 przypadków, nimfomania - 10 przypadków, niedojrzałość psychiczna - 7 przypadków, wada zgody (defectus consensus) - 6 przypadków, alkoholizm - 3 przypadki, homoseksualizm - 2 przypadki oraz w 1 przypadku poważny brak rozeznania oceniającego (defectus debitae discretionis) i satyryzm, co łącznie obejmuje 287 spraw.

Przyczyną takiego stanu rzeczy był m.in. brak jednoznacznego i wyczerpującego sformułowania w Kodeksie prawa kanonicznego z 1917 roku kwestii wpływu anomalii natury psychicznej na zdolność podmiotu do skutecznego wyrażenia zgody małżeńskiej, w przeciwieństwie do ustaleń zawartych w aktualnej normatywie kodeksowej, konkretnie zaś w 3 rozwinięciach kan. 1095 - traktujących o habitualnym braku

${ }_{17}$ Por. wyrok c. Palazzini z 16.07.1969, sRrdec. 61 (1969), s. 805. 
używania rozumu (n. 1), poważnym braku rozeznania oceniającego co do praw i obowiązków małżeńskich wzajemnie przekazywanych i przyjmowanych (n. 2) czy też o niezdolności do podjęcia istotnych obowiązków małżeńskich z przyczyn natury psychicznej (n. 3). Nie oznacza to jednak, iż sądownictwo kościelne nie orzekało nieważności małżeństwa w przypadkach, w których przyczyną takowej było poważne zaburzenie natury psychicznej, deformujące poznanie i wolę jednego lub obydwojga nupturientów. Przede wszystkim należy zauważyć, że sam kodeks z 1917 roku stanowił w kan. $1081 \$ 1$, iż „małżeństwo stwarza zgoda stron między osobami prawnie do tego zdolnymi, wyrażona zgodnie z prawem [...]"’, a jego sukcesywny paragraf, wskazując, że „zgoda małżeńska jest aktem woli, poprzez który każda z dwu stron przekazuje i przyjmuje trwałe i wyłączne prawo do ciała, skierowane poprzez właściwy sobie akt do zrodzenia potomstwa"19, umożliwiał procesowe poszukiwanie takich zaburzeń, które w sposób bezsporny eliminowałyby zdolność podmiotu do wyrażenia konsensu małżeńskiego w ogóle. Ponadto w dyspozycji kan. $1982^{20}$ prawodawca kościelny wskazywał na amencję jako formę niezdolności psychicznej do zawarcia małżeństwa, ocenianą praktycznie pod kątem jej wpływu na działanie rozumu (usus rationis) i woli (deliberatio voluntatis) ${ }^{21}$.

Jak wstępnie zauważa Pierantonio Pavanello (za którym pragniemy poniżej ukazać doktrynalno-judykaturalny wpływ doktryny i orzecznictwa na proces formowania się n. 3 kan. 1095 aktualnego Kodeksu prawa kanonicznego $)^{22}$, powyższe kryterium natury statycznej zintegrowane z czynnikiem dynamicznym, jakim jest discretio iudicii matrimonio proportionata, stało się impulsem i punktem wyjścia do poszukiwań

${ }^{18}$ KPK 17, kan. $1081 \S 1$ : „Matrimonium facit partium consensus inter personas iure habiles legitime manifestatus [...]".

19 KPK 17, kan. $1081 \S 2$ : „Consensus matrimonialis est actus voluntatis quo utraque pars tradit et acceptat ius in corpus, perpetuum et exclusivum, in ordine ad actus per se aptos ad prolis generationem".

${ }^{20}$ Co warte podkreślenia, wspomniana dyspozycja znajduje się w jednym z artykułów zawartych w KPK 17 (art. II, De inspectione corporali), poświęconych dowodzeniu w sprawach małżeńskich.

${ }^{21}$ Por. P. Pavanello, Il requisito della perpetuità nell'incapacità di assumere le obbligazioni essenziali del matrimonio (Can. 1095, 3º), Roma 1994, s. 8.

${ }^{22}$ Por. P. Pavanello, Il requisito..., dz. cyt., s. 8-16. 
odpowiedzi na pytanie o nieważność małżeństwa spowodowaną nie tyle poważnym zaburzeniem władz intelektu i woli, ile niezdolnością do podjęcia (a zatem i wypełnienia) istotnych obowiązków małżeńskich z przyczyn natury psychicznej ${ }^{23}$.

Obszarem, w jakim zaczęła wyłaniać się odrębność tego powodu nieważności, były zaburzenia o charakterze seksualnym, uniemożliwiające podmiotowi dysponowanie przedmiotem zgody małżeńskiej i jej istotnymi elementami, tj. wyłącznością i trwałością ${ }^{24}$.

Pojawiła się także tendencja, aby traktować anomalie seksualne (np. nimfomanię) analogicznie do przeszkody niemocy płciowej (impotentia coëundi), definiując je jako przejaw niemocy o charakterze moralnym (impotentia moralis), uniemożliwiającej przyjęcie wyłączności i trwałości prawa do ciała jako formalnego przedmiotu zgody małżeńskiej ${ }^{25}$.

Warto wspomnieć także o krótkotrwałych próbach umiejscowienia niezdolności do dysponowania przedmiotem zgody małżeńskiej w obszarze fenomenu symulacji tejże zgody ${ }^{26}$. Taki sposób rozumowania traktował np. podmiotową niemożliwość dochowania wierności będącą skutkiem anomalii psychoseksualnej jako causa simulandi przeważającą nad causa contrahendi $\mathrm{z}$ racji osadzenia tej pierwszej w strukturze osobowościowej podmiotu. Zostało to jednak uznane za niesłuszne, gdyż nie można wykluczyć czegoś, czego się nie posiada; ponadto zaburzenie psychiczne dotyka zgody małżeńskiej, nie tyle powodując jej symulację, ile eliminując w podmiocie używanie rozumu bądź poważnie ograniczając rozeznanie oceniające lub też uniemożliwiając przyjęcie jednego czy wielu istotnych obowiązków małżeńskich ${ }^{27}$.

Finalnie należy zaznaczyć tendencję do przedstawiania niezdolności do podjęcia istotnych obowiązków małżeńskich jako defectus obiecti consensus. Zgodnie z ujęciem tej koncepcji wskutek anomalii natury

${ }^{23}$ Por. A. C. Jemolo, Il matrimonio nel Diritto Canonico, Milano 1941, s. 132.

${ }^{24}$ Por. wyrok c. Teodori z 19.01.1940, SRRDec. 32 (1940), s. 90; wyrok c. Jullien z 16.10.1942, SRRDec. 34 (1942), s. 775-781.

${ }^{25}$ Por. wyrok c. Sabbatani z 21.06.1957, SRRDec. 49 (1957), s. 503.

${ }^{26}$ Takie ujęcie zostało zawarte w 2 wyrokach: c. Lefebvre z 26.04.1958, SRRDec. 50 (1958), s. 277-281 i c. Lefebvre Z 19.12.1959, SRRDec. 51 (1959), s. 609-614.

${ }^{27}$ Por. wyrok c. Anné z 17.01.1967, sRrdec. 59 (1967), s. 28. 
psychicznej niemożliwe jest wyrażenie przedmiotu konsensu małżeńskiego bądź jego istotnego elementu, jak np. wyłączność ${ }^{28}$.

Sukcesywnie formalny przedmiot zgody małżeńskiej znalazł swoje rozszerzenie w pojęciu wspólnoty życia (communio vitae) wraz z wynikającymi zeń obowiązkami ${ }^{29}$.

$\mathrm{Na}$ podstawie podanych na początku niniejszego paragrafu danych można wstępnie przyjąć, że sędziowie w diecezjalnym sądzie tarnowskim dość wyraźnie oddzielali nieważność małżeństwa wynikającą z choroby psychicznej podmiotu od tej spowodowanej innymi anomaliami, które $\mathrm{z}$ racji swego zakotwiczenia $\mathrm{w}$ psychice czyniły daną osobę niezdolną do stworzenia wspólnoty małżeńskiej. W odniesieniu jednak do tej ostatniej sfery często nie byli konsekwentni, formułując zamiennie tytuł nieważności przy użyciu terminów takich jak „niezdolność” i „niedojrzałość, a w niektórych przypadkach wskazując wprost na psychiczną przyczynę tejże nieważności, jak np. alkoholizm.

Wskutek tego sporządzenie szczegółowej i wyczerpującej klasyfikacji zaburzeń psychicznych rozumianych jako przyczyna niezdolności podmiotu do wyrażenia konsensu małżeńskiego, a ujmowanych w poszczególnych tytułach spraw rozpatrywanych w sądzie tarnowskim w okresie obowiązywania kodyfikacji pio-benedyktyńskiej, z racji obszerności i złożoności zagadnienia jest zadaniem wymagającym odrębnego opracowania.

Warto również zaznaczyć, że pomimo ogólnej tendencji do rozdzielania sfer symulacji i niezdolności zdarzały się jednak przypadki chociażby ujęcia nimfomanii w kontekście wykluczenia zgody małżeńskiej ${ }^{30}$, co, jak zaznaczyliśmy powyżej, zostało bardzo szybko zarzucone przez judykaturę rotalną.

${ }^{28}$ Por. wyrok c. Anné z 17.01.1967, srrdec. 59 (1967), s. 23-36. Ponens wskazuje tutaj na nimfomanię, która choć nie dotyka formalnych elementów zgody małżeńskiej, takich jak poznanie oceniające oraz wola w kontekście ich działania, eliminuje jednak istotny element jej przedmiotu, jakim jest wyłączność przekazywanego prawa do ciała.

${ }^{29}$ Por. wyrok c. Anné z 25.02.1969, sRrdec. 61 (1969), s. 183-184.

${ }^{30}$ Por. np. wyrok c. Pycior z 20.06.1978 (nr 1259); wyrok c. Kos z 16.10.1980 (nr 1240). 


\section{Zakończenie}

Podsumowując niniejsze rozważania, pierwszorzędnie należy zasygnalizować symptomatyczną ewolucję częstotliwości występowania w praktyce sądu tarnowskiego ujętych w opracowaniu tytułów nieważności. O ile bowiem w pierwszej połowie badanego okresu zdecydowanie dominuje tytuł przymusu i bojaźni, o tyle w połowie lat 70. w sposób wyraźny zaczynają przeważać symulacja zgody małżeńskiej (jak zaznaczyliśmy, niemalże wyłącznie na sposób jej całkowitego wykluczenia), a także niezdolność do wyrażenia konsensu małżeńskiego wskutek przyczyn natury psychicznej. Jak można zauważyć, ostatni z tytułów, biorąc pod uwagę również jego normatywne ujęcie, zwłaszcza to zawarte w n. 3 kan. 1095 kodeksu Jana Pawła II, pozostaje aż do chwili obecnej bezsprzecznie wiodący w sprawach o stwierdzenie nieważności małżeństwa prowadzonych przez trybunał tarnowski.

Przyczyn takiego stanu rzeczy można wskazać kilka. Pierwszą z nich, jak zaznaczyliśmy powyżej, jest trwający od lat 40. ubiegłego stulecia ewolucyjny proces wyodrębniania się w orzecznictwie rotalnym i doktrynie tytułu niezdolności do podjęcia istotnych obowiązków małżeńskich z przyczyn natury psychicznej. Bez wątpienia miało to wpływ na prawną świadomość pracowników trybunałów lokalnych, w tym tarnowskiego, stopniowo i nierzadko intuicyjnie przyjmujących do rozpatrzenia sprawy, w których przyczyną nieważności były już nie tyle poważne zaburzenia intelektu bądź woli, odnoszące się do stricte psychologicznych aspektów kształtu konsensu małżeńskiego, ile anomalie dotykające jego przedmiotu, czyli wyłącznego i trwałego prawa do ciała współmałżonka i sukcesywnie sfery tworzącej rozumianą personalistycznie przestrzeń dobra samych małżonków oraz budowanej przez nich wspólnoty życia i miłości.

Równolegle z powyższym faktorem zmieniała się zapewne także świadomość wiernych ${ }^{31}$, stopniowo dostrzegających, że nie tylko choroba psychiczna współmałżonka, impotencja bądź wywarty na zawarcie małżeństwa przymus zewnętrzny, lecz także chociażby głęboko ugruntowana

${ }^{31}$ Należy dodać, że w odniesieniu do obecnego stanu rzeczy, kształtowanego przez szeroko praktykowane poradnictwo kanoniczne, dokonywało się to bardzo powoli. W analizowanym bowiem okresie dostępną wiernemu funkcję konsultacyjną w sprawach małżeńskich zasadniczo spełniał właściwy mu duszpasterz. 
niedojrzałość emocjonalna (w kanonicznym rozumieniu tego pojęcia) stanowiła przyczynę orzeczenia nieważności małżeństwa, gdyż czyniła kontrahenta niezdolnym do stworzenia intymnej wspólnoty całego życia, jaką jest małżeństwo, mimo że nie wykluczała go ze sfery życia społecznego i zawodowego. Jako egzemplaryczne uszczegółowienie tego aspektu można wskazać na decyzyjne uzależnienie od rodziców czy też głęboko osadzony egoizm, wyrażający się w całkowitym braku troski o współmałżonka, dom i potomstwo.

Trudno jednak uznać powolny spadek częstotliwości wprowadzania spraw z tytułu przymusu i bojaźni za skutek ewentualnie zmieniających się warunków rodzinno-społecznych, w tym wzajemnych relacji rodziców i dzieci, wraz z ich postępującą autonomizacją, nie można bowiem zauważyć, aby proces ten $\mathrm{w}$ realiach diecezji tarnowskiej zaczął się dokonywać w latach 7o. ubiegłego stulecia. Niewykluczone jednak, że w sądowej praktyce rozpoznawania spraw zaczęto dostrzegać, iż na decyzję o zawarciu małżeństwa wpływa przymus mający swe źródło nie tyle w czynnikach zewnętrznych (działaniach gnębiciela), ile w zaburzonej psychice kontrahenta, deformując ostateczny wybór stanu małżeńskiego (tzw. brak wolności wewnętrznej, regulowany aktualnym n. 2 kan. 1095 KPK).

Nie można także pominąć zauważalnego zjawiska kumulowania tytułów nieważności małżeństwa w poszczególnych sprawach, co w praktyce sądu tarnowskiego pojawia się w drugiej połowie lat 70. Biorąc pod uwagę zrozumiałą w wielu wypadkach konieczność takiego ukierunkowania procesu, motywowaną argumentami stron zawartymi w skardze powodowej i w odpowiedzi na nią, można jednak hipotetycznie przyjąć, że w pewnych przypadkach było to wynikiem swoistej asekuracji kolegium sędziowskiego na wypadek potrzeby przypisania źródła nieważności małżeństwa przyczynie, która na etapie przyjmowania sprawy nie była jeszcze dostatecznie dookreślona.

Konkludując, należy stwierdzić, że materialny obszar procesowej działalności diecezjalnego sądu tarnowskiego w powojennym okresie obowiązywalności kodyfikacji pio-benedyktyńskiej sukcesywnie się rozszerzał, czy to ze względu na rosnącą liczbę wpływających spraw, czy też wskutek rozwoju dokonującego się na płaszczyznach doktryny i orzecznictwa rotalnych, zwłaszcza w kwestiach dotyczących nieważności małżeństwa z przyczyn natury psychicznej. 
Finalnie wyrażamy także nadzieję, że niniejszy artykuł pomimo zrozumiałych ograniczeń będzie inspiracją do przeprowadzenia kompleksowego opracowania w perspektywie historycznej tytułów nieważności małżeństwa rozpatrywanych przez Sąd Diecezjalny w Tarnowie. 
